Biogeosciences, 10, 4577-4589, 2013

www.biogeosciences.net/10/4577/2013/

doi: $10.5194 /$ bg-10-4577-2013

(C) Author(s) 2013. CC Attribution 3.0 License.

\title{
Ammonia emissions from deciduous forest after leaf fall
}

\author{
K. Hansen ${ }^{1}$, L. L. Sørensen ${ }^{2}$, O. Hertel ${ }^{1,2}$, C. Geels ${ }^{2}$, C. A. Skjøth ${ }^{3,4, *}$, B. Jensen ${ }^{2}$, and E. Boegh ${ }^{1}$ \\ ${ }^{1}$ Department of Environmental, Social and Spatial Change, Roskilde University, Roskilde, Denmark \\ ${ }^{2}$ Department of Environmental Science, Aarhus University, Roskilde, Denmark \\ ${ }^{3}$ Department of Physical Geography and Ecosystems Science, Lund University, Lund, Sweden \\ ${ }^{4}$ National Pollen and Aerobiology Research Unit, Charles Darwin Building, University of Worcester, Henwick Grove, \\ Worcester, WR2 6AJ, UK \\ * formerly at: Department of Environmental Science, Aarhus University, Roskilde, Denmark
}

Correspondence to: K. Hansen (krih@ruc.dk)

Received: 9 July 2012 - Published in Biogeosciences Discuss.: 7 November 2012

Revised: 21 May 2013 - Accepted: 7 June 2013 - Published: 9 July 2013

\begin{abstract}
The understanding of biochemical feedback mechanisms in the climate system is lacking knowledge in relation to bi-directional ammonia $\left(\mathrm{NH}_{3}\right)$ exchange between natural ecosystems and the atmosphere. We therefore study the atmospheric $\mathrm{NH}_{3}$ fluxes during a 25-day period during autumn 2010 (21 October to 15 November) for the Danish beech forest Lille Bøgeskov to address the hypothesis that $\mathrm{NH}_{3}$ emissions occur from deciduous forests in relation to leaf fall. This is accomplished by using observations of vegetation status, $\mathrm{NH}_{3}$ fluxes and model calculations. Vegetation status was observed using plant area index (PAI) and leaf area index (LAI). $\mathrm{NH}_{3}$ fluxes were measured using the relaxed eddy accumulation (REA) method. The REA-based $\mathrm{NH}_{3}$ concentrations were compared to $\mathrm{NH}_{3}$ denuder measurements. Model calculations of the atmospheric $\mathrm{NH}_{3}$ concentration were obtained with the Danish Ammonia MOdelling System (DAMOS). The relative contribution from the forest components to the atmospheric $\mathrm{NH}_{3}$ flux was assessed using a simple two-layer bi-directional canopy compensation point model. A total of $57.7 \%$ of the fluxes measured showed emission and $19.5 \%$ showed deposition. A clear tendency of the flux going from deposition of $-0.25 \pm 0.30 \mu \mathrm{g} \mathrm{NH} \mathrm{NH} \mathrm{m}^{-2} \mathrm{~s}^{-1}$ to emission of up to $0.67 \pm 0.28 \mu \mathrm{g} \mathrm{NH}_{3}-\mathrm{N} \mathrm{m}^{-2} \mathrm{~s}^{-1}$ throughout the measurement period was found. In the leaf fall period (23 October to 8 November), an increase in the atmospheric $\mathrm{NH}_{3}$ concentrations was related to the increasing forest $\mathrm{NH}_{3}$ flux. Following leaf fall, the magnitude and temporal structure of the measured $\mathrm{NH}_{3}$ emission fluxes could be adequately reproduced with the bi-directional resistance model; it suggested the for-
\end{abstract}

est ground layer (soil and litter) to be the main contributing component to the $\mathrm{NH}_{3}$ emissions. The modelled concentration from DAMOS fits well the measured concentrations before leaf fall, but during and after leaf fall, the modelled concentrations are too low. The results indicate that the missing contribution to atmospheric $\mathrm{NH}_{3}$ concentration from vegetative surfaces related to leaf fall are of a relatively large magnitude. We therefore conclude that emissions from deciduous forests are important to include in model calculations of atmospheric $\mathrm{NH}_{3}$ for forest ecosystems. Finally, diurnal variations in the measured $\mathrm{NH}_{3}$ concentrations were related to meteorological conditions, forest phenology and the spatial distribution of local anthropogenic $\mathrm{NH}_{3}$ sources. This suggests that an accurate description of ammonia fluxes over forest ecosystems requires a dynamic description of atmospheric and vegetation processes.

\section{Introduction}

Atmospheric ammonia $\left(\mathrm{NH}_{3}\right)$ plays an important role in air quality and critical load studies of natural and semi-natural ecosystems. $\mathrm{NH}_{3}$ is a reactive nitrogen compound $\left(\mathrm{N}_{\mathrm{r}}\right)$, which contributes to the formation of ammonium aerosols $\left(\mathrm{NH}_{4}^{+}\right)$through atmospheric chemical reactions (Hertel et al., 2012) and is leading to deposition to terrestrial and marine ecosystems (de Leeuw et al., 2003; Duce et al., 2008; Massad et al., 2010; Zhang et al., 2010). An enhanced load of $\mathrm{N}_{\mathrm{r}}$ in terrestrial ecosystems can increase the rate of acidification and eutrophication processes and thereby reduce biodiversity 
and increase ecosystem vulnerability to extreme weather and insect attacks (Bobbink et al., 2010; Erisman et al., 2007; Stevens et al., 2004; Sutton et al., 2011; Xiankai et al., 2008). In nutrient-limited ecosystems, nitrogen deposition can also work to increase the $\mathrm{C}$-sequestration and growth of vegetation (de Vries et al., 2009).

Budgets of atmospheric $\mathrm{NH}_{3}$ for water and land areas are being carried out using atmospheric models (e.g. Bartnicki et al., 2011; de Leeuw et al., 2003; Geels et al., 2012a; Hertel et al., 2003; Langner et al., 2009). Model calculations indicate that particular forest ecosystems are exposed to critical load exceedances of nitrogen (Geels et al., 2012b; Hertel et al., 2013). Generally the understanding of major biochemical feedback mechanisms in the terrestrial climate system suffers from large uncertainties (Arneth et al., 2010) and lacking knowledge of the bi-directional (two-way) $\mathrm{NH}_{3}$ exchange between the land/water surface and the atmosphere (Massad et al., 2010). Because natural $\mathrm{NH}_{3}$ emissions have been assessed to a rather limited extent (Massad et al., 2010; Nemitz et al., 2001), they are not yet included in operational air pollution models (Menut and Bessagnet, 2010).

Limited field studies have shown that the deposition velocity of $\mathrm{NH}_{3}$ for forests is relatively high and variable (Andersen et al., 1999; Duyzer et al., 1994; Wyers et al., 1992) and thereby complicates the understanding of forest $\mathrm{NH}_{3}$ exchange processes and makes model validation difficult. High deposition velocities for forests were simulated by four inferential models used across European sites, but large differences (up to factor 3) were found between model results (Flechard et al., 2011).

Sources of atmospheric $\mathrm{NH}_{3}$ are conceptually considered to be anthropogenic (e.g. Gyldenkærne et al., 2005; Hertel et al., 2012) and primarily related to agricultural activities (e.g. Bouwman et al., 1997; Reis et al., 2009). In Europe, agricultural emissions arise from farm buildings (34-43\%), manure $(22-26 \%)$, fertilisers $(17-26 \%)$ and grazing animals (6-10\%) (Skjøth and Geels, 2013). Open water areas (e.g. Barrett, 1998; Sorensen et al., 2003) and natural land areas (e.g. Duyzer et al., 1994) have also been shown to emit $\mathrm{NH}_{3} . \mathrm{NH}_{3}$ emissions from forests are generally not included in official emission inventories (Reis et al., 2009) or the more detailed national inventories (Gyldenkærne et al., 2005; Velthof et al., 2012). However, $\mathrm{NH}_{3}$ flux studies of forests indicate bi-directional flux patterns for $\mathrm{NH}_{3}$ (Andersen et al., 1999; Erisman and Wyers, 1993; Sutton et al., 1997; Wyers and Erisman, 1998). Emissions of $\mathrm{NH}_{3}$ from ecosystems are found to take place when the atmospheric $\mathrm{NH}_{3}$ concentration is lower than the stomatal $\mathrm{NH}_{3}$ compensation point (Wichink Kruit et al., 2007; Mattsson et al., 2009; Schjoerring et al., 1998), from decomposing leaf litter (David et al., 2009; Nemitz et al., 2000a), and by cuticular desorption (Pryor et al., 2001). Furthermore, Wang et al. (2011) discovered a seasonal dependence of the $\mathrm{NH}_{3}$ compensation points of beech leaves and found largest emission potential in relation to the late senescent leaves. The effects of leaf $\mathrm{NH}_{3}$ emissions in rela-

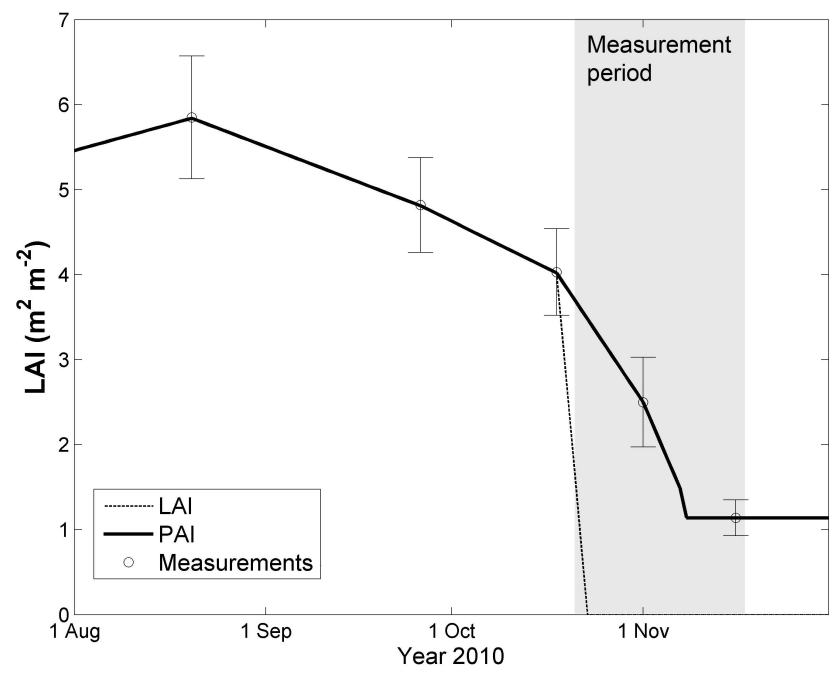

Fig. 1. Plant area index (PAI) and leaf area index (LAI) of Lille Bøgeskov for autumn 2010. Open circles show the LAI-2000 measurements of PAI with the standard deviations indicated by the error bars. Daily values of PAI (solid line) and of LAI (dotted line) are found from linear interpolation. The grey rectangular area shows the ammonia $\left(\mathrm{NH}_{3}\right)$ measurement period (21 October to 15 November).

tion to leaf fall still remain to be quantified, particularly at canopy scale.

The main objective of this paper was to assess the $\mathrm{NH}_{3}$ flux $F_{\mathrm{NH}_{3}}$ for a Danish deciduous forest in the leaf senescence period using high-resolution atmospheric measurements and local-scale concentration-deposition modelling. We investigate the hypothesis that $\mathrm{NH}_{3}$ emissions occur from deciduous forests in relation to leaf fall by correlating this with $\mathrm{NH}_{3}$ emissions and explore the importance of including such emissions in models. To do this, half-hourly measurements of the $\mathrm{NH}_{3}$ concentration and flux were conducted using the relaxed eddy accumulation (REA) technique for a Danish beech forest site in the leaf fall period 21 October to 15 November 2010 (Fig. 1). The measured concentrations were compared to model calculations using the Danish Ammonia MOdelling System (DAMOS), and a simple two-layer bi-directional canopy compensation point model was used to interpret the measured fluxes.

\section{Methods}

\section{$2.1 \quad$ Field site}

The field station (Lille Bøgeskov) is located in the central part of Zealand $\left(55^{\circ} 29^{\prime} 13^{\prime \prime} \mathrm{N}, 11^{\circ} 38^{\prime} 45^{\prime \prime} \mathrm{E}\right)$ with a surrounding landscape characterised primarily by agricultural activities. Lille Bøgeskov covers approximately $2.5 \mathrm{~km}^{2}$ with the field station located in the centre of the forest. The field station includes a flux tower $(57 \mathrm{~m})$ and a scaffolding tower (24 m) (Fig. 2). 
The forest consists predominantly of $82 \mathrm{yr}$-old beech trees (Fagus sylvatica) with an average canopy height of $26 \mathrm{~m}$. Scattered stands of conifers constitute about $20 \%$ of the forest area. The mean summer peak of LAI has been measured to be 4.6 since year 2000 with maximum LAI just above 5 (Pilegaard et al., 2011). In 2010, defoliation was observed to begin on 23 October and leaf fall to end on 8 November.

The soils are brown and consist of Alfisols and Mollisols. Dead plant material consisting mainly of leaves and twigs from the beech trees constitutes the top $0-3 \mathrm{~cm}$. Below is a $10-40 \mathrm{~cm}$ deep organic layer. In the upper organic soil layers, the $\mathrm{C} / \mathrm{N}$ ratio is about 20 and the $\mathrm{pH}$ is low (4-5) (Østergård, 2000).

\subsection{Leaf area index}

In order to relate the atmospheric data to forest canopy development, the plant area index (PAI) was measured during the growing season (May-November) every 14-30 days using the LAI-2000 Plant Canopy Analyzer with a $270^{\circ}$ view cap (LAI-2000 PCA). PAI was estimated using one abovecanopy reading and 10 below-canopy readings conducted along an $18 \mathrm{~m}$ transect. The above-canopy readings were performed outside the forest edge. Measurements were made during uniformly overcast sky conditions, as recommended by the manufacturer. In order to assess the leaf area index (LAI), observations of leaf defoliation were used to adjust the PAI data by linear interpolation to zero LAI at the time when there were no more green leaves present in the canopy. The end of the defoliation and leaf fall periods were determined from daily digital photos of the canopy using a camera mounted on top of the tower. The uncertainty of measurements was calculated as the standard deviation of the 10 below-canopy readings.

\subsection{Local meteorological measurements}

The wind components in $\mathrm{x}-, \mathrm{y}$ - and $\mathrm{z}$-directions were measured at $10 \mathrm{~Hz}$ sampling using an ultra-sonic anemometer (Metek-uSonic-3 Scientific) installed above the forest canopy at $34 \mathrm{~m}$ height (Fig. 2). Half-hourly averaged values of wind velocity, wind direction, friction velocity, temperature, and Monin-Obukhov length were calculated from the $10 \mathrm{~Hz}$ sampling. Precipitation, relative humidity, soil temperature, soil water content, and global radiation were obtained from the European Fluxes Database Cluster (www. europe-fluxdata.eu) as described in Pilegaard et al. (2011).

\subsection{Ammonia flux measurements}

\subsubsection{Relaxed eddy accumulation (REA)}

The vertical turbulence-driven flux of $\mathrm{NH}_{3}\left(F_{\mathrm{NH}_{3}}\right)$ was estimated using the REA technique (Businger and Oncley, 1990). REA simplifies the eddy accumulation methods (Hicks and Mcmillen, 1984), where the sampling speed must

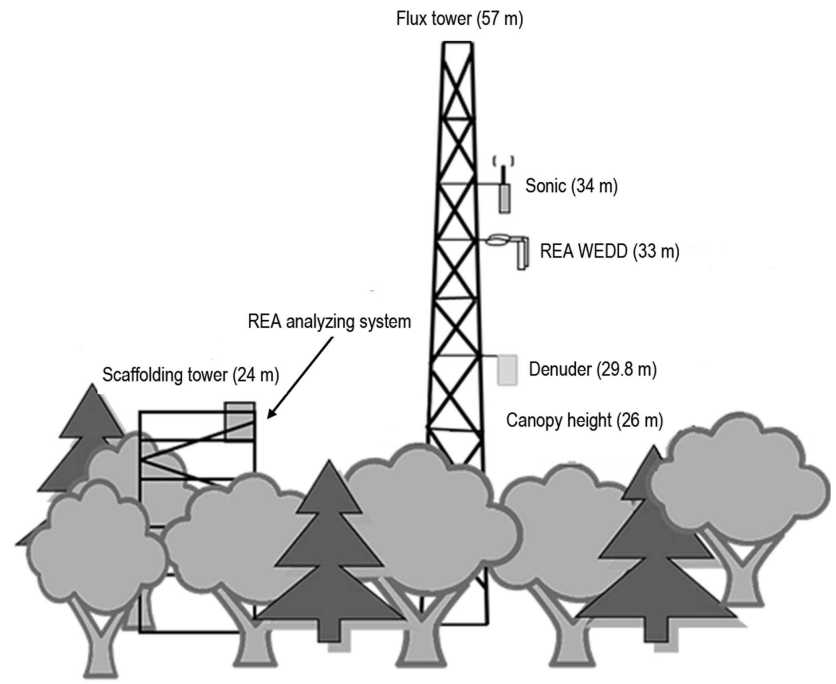

Fig. 2. Instrumental setup in Lille Bøgeskov for atmospheric ammonia $\left(\mathrm{NH}_{3}\right)$ measurements. A flux tower $(57 \mathrm{~m})$ is equipped with a sonic anemometer $(34 \mathrm{~m})$ to measure micro-meteorological parameters, two wet effluent diffusion denuders (WEDDs) for the relaxed eddy accumulation (REA) system $(33 \mathrm{~m})$ and seven glass denuders $(29.8 \mathrm{~m})$ to measure atmospheric $\mathrm{NH}_{3}$. The REA analysing system is located at the top floor of a scaffolding tower $(24 \mathrm{~m})$.

be proportional to the vertical wind velocity, by relaxing the sampling at a constant flow rate (Businger and Oncley, 1990). REA combines measurements of the vertical momentum flux and the difference between the average trace gas concentration of upward and downward moving eddies.

A system to measure canopy-scale $F_{\mathrm{NH}_{3}} \quad\left(\mu \mathrm{g} \mathrm{NH} \mathrm{NH}_{3}^{-}\right.$ $\mathrm{N} \mathrm{m}^{-2} \mathrm{~s}^{-1}$ ) based on the REA technique was installed in the flux tower at the forest field station (Fig. 2) in the period from 21 October to 15 November 2010. Two short breaks occurred due to technical work on the instruments. The system consisted of three parts: (1) a sonic anemometer measuring vertical wind speed, (2) an inlet system, and (3) an analytical detection system (Fig. 3) to detect the concentration signals. The sonic anemometer was located in the mast at a height of $34 \mathrm{~m}$ to control the conditional sampling of atmospheric $\mathrm{NH}_{3}$ in the up- and downdrafts respectively. The inlet system, comprised by two wet effluent diffusion denuders (WEDDs), was located just below the sonic anemometer at $33 \mathrm{~m}$. The WEDDs collected atmospheric $\mathrm{NH}_{3}$ from upward and downward eddies separately by diffusion into a water film (Hensen et al., 2009). The aqueous $\mathrm{NH}_{3}$ solution from the two WEDDs was pumped with a constant flow directly to the analytical detection system which was located at the top floor of a scaffolding tower. A fluorescent compound was produced by mixing $o$-phthaldialdehyde (OPA), sulphite, and the aqueous $\mathrm{NH}_{3}$ solution (Sorensen et al., 1994). The liquid was heated to $60^{\circ} \mathrm{C}$ to enhance the formation of the fluorescent compound before injection into the fluorescence detector. Detailed information of the WEDD and the analytical 
system can be found in Sorensen et al. (1994). To prevent freezing of the fluent when air temperature was near freezing point, the water was mixed with ethanol. The analytical system was calibrated using standard calibration fluids of 0,10 and $25 \mathrm{ppb} \mathrm{NH}_{4}^{+}$. Half-hourly estimates of $F_{\mathrm{NH}_{3}}$ were calculated from Eq. (1):

$F=\beta \sigma_{w}(\chi \uparrow-\chi \downarrow)$,

where $\chi \uparrow$ and $\chi \downarrow$ are the average $\mathrm{NH}_{3}$ concentration in the up- and downdrafts respectively, $\sigma_{w}$ is the standard deviation of the vertical wind velocity $w^{\prime}$, and $\beta$ is a coefficient to be determined by the probability distribution of $w$. The $\beta$ coefficient is well defined for an ideal Gaussian joint frequency distribution of $w$ and $\chi$. However, turbulent transport, especially over very rough surfaces, often violates the underlying assumption of a linear relationship between $w$ and $\chi$ (Ruppert et al., 2006); thus the use of a $\beta_{0}$ coefficient determined from a proxy scalar (such as the sensible heat flux) better reflects the correct $\beta$ coefficient for a certain measurement period. A dynamic deadband was introduced as a threshold for partitioning $\chi \uparrow$ and $\chi \downarrow$ (Businger and Oncley, 1990) where sampling only took place when the vertical wind velocity exceeded a predefined deadband velocity $w_{0}$. The $\beta$-coefficient has to be corrected for the choice of deadband velocity:

$\beta=\beta_{0} \exp \frac{-0.75 \cdot w_{0}}{\sigma_{w}}$,

where $w_{0}$ is the dynamic deadband (set to $0.5 \sigma_{w} \mathrm{~m} \mathrm{~s}^{-1}$ in this study; Hensen et al., 2009), $\beta_{0}$ is the coefficient when $w_{0}=0$, and $\beta_{0}$ was calculated based on the sensible heat flux:

$\beta_{0}=\frac{\overline{w^{\prime} T^{\prime}}}{\sigma_{w} \cdot(T \uparrow-T \downarrow)}$,

where $\overline{w^{\prime} T^{\prime}}$ is the sensible heat flux, and $T \uparrow$ and $T \downarrow$ represent temperatures when the fluctuating component of $w$ is directed upward and downward respectively. According to the theoretical principles of the REA method, $\beta_{0}$ is $\sim 0.6$ for a smooth surface. However, Gao (1995) found $\beta_{0}$ to decrease when measuring close to tall canopies, and Ren et al. (2011) experimentally determined $\beta_{0}$ to $\sim 0.42 \pm 0.02$. Therefore, if the calculated $\beta_{0}$ is less that 0.2 or larger than 0.6 , then $\beta_{0}=0.4$ was used following the value found by Ren et al. (2011).

The measurement uncertainty of $\mathrm{NH}_{3}$ concentration was estimated from the relative uncertainty, based on the mean value of three calibration campaigns conducted during the measurement period. For each calibration, concentration liquids of 0,10 and $25 \mathrm{ppb}$ were used, and the detection limit was estimated. A few measurements on 25 October were found to be lower than the estimated detection limit and excluded from further analysis. The reliability of the $F_{\mathrm{NH}_{3}}$ measurements was assessed by comparing the atmospheric $\mathrm{NH}_{3}$ concentration measurements from the REA system $\left(c_{\mathrm{RNH}_{3}}\right)$ with concentration measurements performed using diffusion denuders $\left(c_{\mathrm{dNH}_{3}}\right)$.

\subsection{Flux partitioning}

The contribution to the atmospheric $\mathrm{NH}_{3}$ flux from the stomatal, cuticular and ground in the forest was assessed by simulating the forest component fluxes $F_{\mathrm{s}}, F_{\mathrm{w}}$ and $F_{\mathrm{g}}\left(\mu \mathrm{g} \mathrm{NH} \mathrm{NH}^{-}\right.$ $\mathrm{N} \mathrm{m}^{-2} \mathrm{~s}^{-1}$ ) using a simple two-layer bi-directional canopy compensation point biosphere-atmosphere modelling approach (Nemitz er al., 2001). The model includes a $\mathrm{NH}_{3}$ stomatal compensation point and allows $\mathrm{NH}_{3}$ emissions from the ground layer caused by e.g. soil emissions or litter decomposition. The $\mathrm{NH}_{3}$ canopy compensation point $\chi_{\mathrm{c}}$ and the component fluxes are calculated as (Nemitz et al., 2001)

$$
\begin{aligned}
& \chi_{\mathrm{c}}=\frac{\chi_{a}\left(R_{\mathrm{a}} R_{\mathrm{b}}\right)^{-1}+\chi_{\mathrm{s}}\left(R_{\mathrm{a}} R_{\mathrm{s}}\right)^{-1}+\left(R_{\mathrm{b}} R_{\mathrm{s}}\right)^{-1}+\left(R_{\mathrm{g}} R_{\mathrm{s}}\right)^{-1}+\chi_{\mathrm{g}}\left(R_{\mathrm{b}} R_{\mathrm{g}}\right)^{-1}}{\left(R_{\mathrm{a}} R_{\mathrm{b}}\right)^{-1}+\left(R_{\mathrm{a}} R_{\mathrm{s}}\right)^{-1}+\left(R_{\mathrm{a}} R_{\mathrm{w}}\right)^{-1}+\left(R_{\mathrm{b}} R_{\mathrm{g}}\right)^{-1}+\left(R_{\mathrm{b}} R_{\mathrm{s}}\right)^{-1}+\left(R_{\mathrm{b}} R_{\mathrm{w}}\right)^{-1}+\left(R_{\mathrm{g}} R_{\mathrm{s}}\right)^{-1}+\left(R_{\mathrm{g}} R_{\mathrm{w}}\right)^{-1}} . \\
& F_{\mathrm{S}}=-\frac{\chi_{\mathrm{c}}-\chi_{\mathrm{S}}}{R_{\mathrm{S}}} \\
& F_{\mathrm{W}}=-\frac{\chi_{\mathrm{c}}}{R_{\mathrm{W}}} \\
& F_{\mathrm{g}}=-\frac{\chi_{(c)-} \chi_{\mathrm{g}}}{R_{\mathrm{g}}}
\end{aligned}
$$

where $\chi_{\mathrm{s}}$ and $\chi_{\mathrm{g}}$ are the stomatal and ground compensation points $\left(\mu \mathrm{g} \mathrm{NH}_{3}-\mathrm{N} \mathrm{m}^{-3}\right) . R_{\mathrm{a}}, R_{\mathrm{b}}, R_{\mathrm{S}}, R_{\mathrm{w}}$ and $R_{\mathrm{g}}$ are the aerodynamic, boundary layer, stomatal, cuticular, and ground resistances $\left(\mathrm{s} \mathrm{m}^{-1}\right)$, respectively. The total forest flux $F_{\mathrm{t}}$ $\left(\mu \mathrm{g} \mathrm{NH} \mathrm{N}_{3}-\mathrm{N} \mathrm{m}^{-2} \mathrm{~s}^{-1}\right)$ is calculated as the sum of the three component fluxes. The leaf physiological parameters such as apoplast $\mathrm{pH}$ and $\mathrm{NH}_{4}^{+}$concentration are normally used to calculate the stomatal emission potential $\Gamma_{\mathrm{s}}\left[\mathrm{NH}_{4}^{+} / \mathrm{H}^{+}\right]$and the stomatal compensation point $\chi_{\mathrm{s}}$, and for this purpose a value for $\Gamma_{\mathrm{s}}$ of 250 found by Wang et al. (2011) in the late senescent period for the forest was used. The ground layer emission potential $\Gamma_{\mathrm{g}}\left[\mathrm{NH}_{4}^{+} / \mathrm{H}^{+}\right]$was fitted to $F_{\mathrm{g}}$ (Eq. 7). It was found that, after leaf fall, a constant $\Gamma_{\mathrm{g}}$ value of 80000 reproduces the measured net flux reasonably well. It should be noted however that $R_{\mathrm{g}}$ is calculated as the sum of an in-canopy resistance $R_{\mathrm{ac}}$ and a ground boundary layer resistance $R_{\mathrm{bg}}$ that are parameterised for agricultural crops and free-water surfaces, respectively. Uncertainties regarding these parameterisations therefore exist when applied to a forest ecosystem.

\subsection{Denuder measurement}

Atmospheric $\mathrm{NH}_{3}$ concentration $c_{\mathrm{dNH}_{3}}\left(\mu \mathrm{g} \mathrm{NH}_{3}-\mathrm{N} \mathrm{m}^{-3}\right)$ at $29.8 \mathrm{~m}$ height (Fig. 2) was sampled using seven $15 \mathrm{~cm}$ long glass diffusion denuders (Ferm, 1979) for the period 26 October to 11 November. The denuders were coated with a solution of citric acid in methanol which effectively captures $\mathrm{NH}_{3}$. Air was pumped through the denuders at $300 \mathrm{~mL} \mathrm{~min}^{-1}$. Chemical analyses of denuders were performed using ion chromatography. The uncertainty of measurements was estimated as the standard deviation of the 
three denuders, and the detection limit was calculated as 3 times the standard deviation of the unexposed denuders (blank) to be $0.003 \mu \mathrm{g} \mathrm{NH}_{3}-\mathrm{N} \mathrm{m}^{-3}$, following the method used by Andersen et al. (1999).

\subsection{Model calculations using DAMOS}

The atmospheric $\mathrm{NH}_{3}$ deposition and concentration $\left(c_{\mathrm{mNH}_{3}}\right)$ was modelled using the DAMOS system (Geels et al., 2012b). DAMOS is a combination of the regional-scale DEHM model (Brandt et al., 2012; Christensen, 1997) and the local-scale Gaussian dispersion/deposition model OMLDEP (Sommer et al., 2009). DEHM includes a detailed $\mathrm{NH}_{3}$ emission model (Gyldenkærne et al., 2005; Skjøth et al., 2004, 2011) and provided in this study the wet $\mathrm{NH}_{3}$ deposition and upwind boundary conditions for the local-scale OML-DEP model. OML-DEP was used to simulate atmospheric $\mathrm{NH}_{3}$ concentrations and deposition rates using a oneway dry deposition scheme (Simpson et al., 2003), a high spatial resolution $(100 \mathrm{~m})$ land cover (Nielsen et al., 2000) and local field $\mathrm{NH}_{3}$ emissions (Gyldenkærne et al., 2005; Skjøth et al., 2004). Estimates of field emissions considered the annual animal production in each agricultural building, and the location of buildings and storage facilities were represented by their geographical coordinates (Fig. 4). Temporal changes of emissions due to variable meteorological conditions, particularly air temperature and length of local growing season, were also taken into account (Skjøth et al., 2011, 2004). OML-DEP provided hourly simulations throughout the measurement period for $40 \times 40$ receptor points in a $16 \mathrm{~km} \times 16 \mathrm{~km}$ grid. The flux tower was located in the centre of the modelling domain. A full description of DAMOS can be found in Geels et al. (2012b) and Hertel et al. (2013).

\section{Results}

\subsection{Meteorological and soil observations}

The meteorological and soil conditions in the flux measurement period (21 October to 15 November 2010) are presented in Fig. 5. A series of frontal passages characterised the environmental conditions which caused winds to primarily originate from the west and southwest although interrupted by shorter periods of northerly winds between the 1/2 November and 8/9 November (Fig. 5a). The friction velocity varied mainly between 0 and $1 \mathrm{~m} \mathrm{~s}^{-1}$; however, during the period 3-14 November, three episodes with $u_{*}$ larger than $1 \mathrm{~m} \mathrm{~s}^{-1}$ were observed with wind speeds of up to $8 \mathrm{~m} \mathrm{~s}^{-1}$ (Fig. 5b). The period with westerly winds was characterised by near-neutral situations, while the shorter periods with more northerly winds had episodes with either stable or unstable conditions (Fig. 5f). Observed temperatures remained in the range $5-14{ }^{\circ} \mathrm{C}$ until 7 November, after which temperatures decreased and stabilised at $2-5^{\circ} \mathrm{C}$ during the rest of the period (Fig. 5d). The same pattern was seen in soil tem-

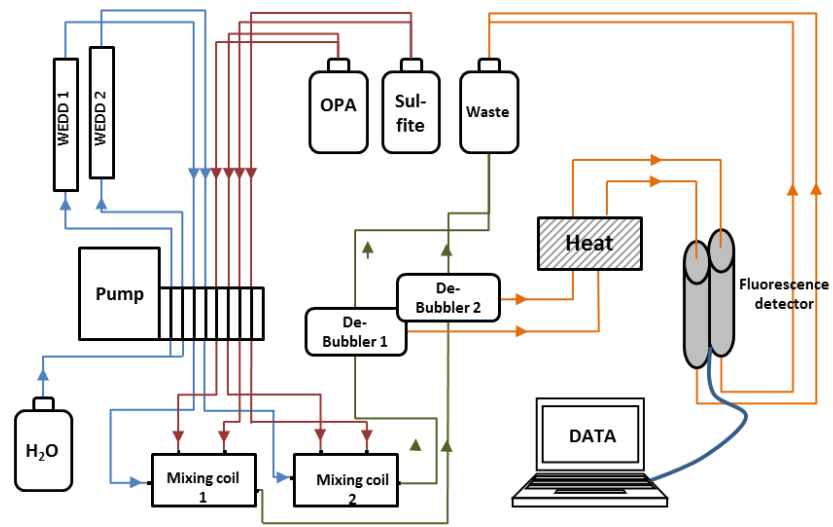

Fig. 3. Schematic overview of the relaxed eddy accumulation (REA) analysing system for $\mathrm{NH}_{3}$ flux measurements. The path of the liquid mixture of $\mathrm{NH}_{3}$ and $\mathrm{H}_{2} \mathrm{O}$ through the wet effluent diffusion denuders (WEDDs) (one for updraft eddies of air and one for downdrafts) is indicated with the blue line, the mixing with the chemical reagents $o$-phthaldialdehyde (OPA) and sulphite with the red line, the path through the de-bubbler with green and finally through the heating coiler and fluorescence detector with yellow.

perature, which decreased from 9 to $5^{\circ} \mathrm{C}$ during the period (Fig. 5e). The period 21 October to 7 November had episodes with a few $\mathrm{mm}$ of rain almost every day (Fig. $5 \mathrm{~g}$ ), which led to high soil water content and high relative air humidity (Fig. $5 \mathrm{i}$ and h). It did not rain from 8 to 14 November.

\subsection{High-resolution ammonia fluxes}

Figure $6 \mathrm{~b}$ shows the measured $\mathrm{NH}_{3}$ fluxes. $F_{\mathrm{NH}_{3}}$ varied from $-0.25 \pm 0.30 \mu \mathrm{g} \mathrm{NH}_{3}-\mathrm{N} \mathrm{m}^{-2} \mathrm{~s}^{-1}$ in the beginning of the measurement period to $0.67 \pm 0.28 \mu \mathrm{g} \mathrm{NH}_{3}-\mathrm{N} \mathrm{m}^{-2} \mathrm{~s}^{-1}$ in the end of the period. The mean flux was $0.06 \pm 0.17 \mu \mathrm{g} \mathrm{NH}_{3}-$ $\mathrm{N} \mathrm{m}^{-2} \mathrm{~s}^{-1}$ (Table 1). A clear tendency of $F_{\mathrm{NH}_{3}}$ going from negative (deposition) to positive (emission) fluxes was seen throughout the measurement period. Even though estimates were related to large uncertainties $\left(0.006-0.344 \mu \mathrm{g} \mathrm{NH} \mathrm{N}_{3}\right.$ $\mathrm{N} \mathrm{m}^{-2} \mathrm{~s}^{-1}$ ), the occurrence of emissions was convincing. Comparing LAI and $F_{\mathrm{NH}_{3}}$ during leaf fall showed a gradual increase of $F_{\mathrm{NH}_{3}}$ from negative to positive fluxes following defoliation (Fig. 6a and b). When defoliation ended (LAI reached zero) on 23 October, the deposition decreased towards zero (non-existent flux). In the leaf fall period ( $23 \mathrm{Oc}-$ tober to 8 November), $F_{\mathrm{NH}_{3}}$ gradually turned to positive fluxes, and a peak $\mathrm{NH}_{3}$ emission of $0.50 \mu \mathrm{g} \mathrm{NH}_{3}-\mathrm{N} \mathrm{m}^{-2} \mathrm{~s}^{-1}$ was reached on 3 November. Following leaf fall, $F_{\mathrm{NH}_{3}}$ stayed positive and three emission peaks $(8 / 9,10$ and 12 November) of up to $0.67 \pm 0.28 \mu \mathrm{g} \mathrm{NH}_{3}-\mathrm{N} \mathrm{m}^{-2} \mathrm{~s}^{-1}$ were observed. 

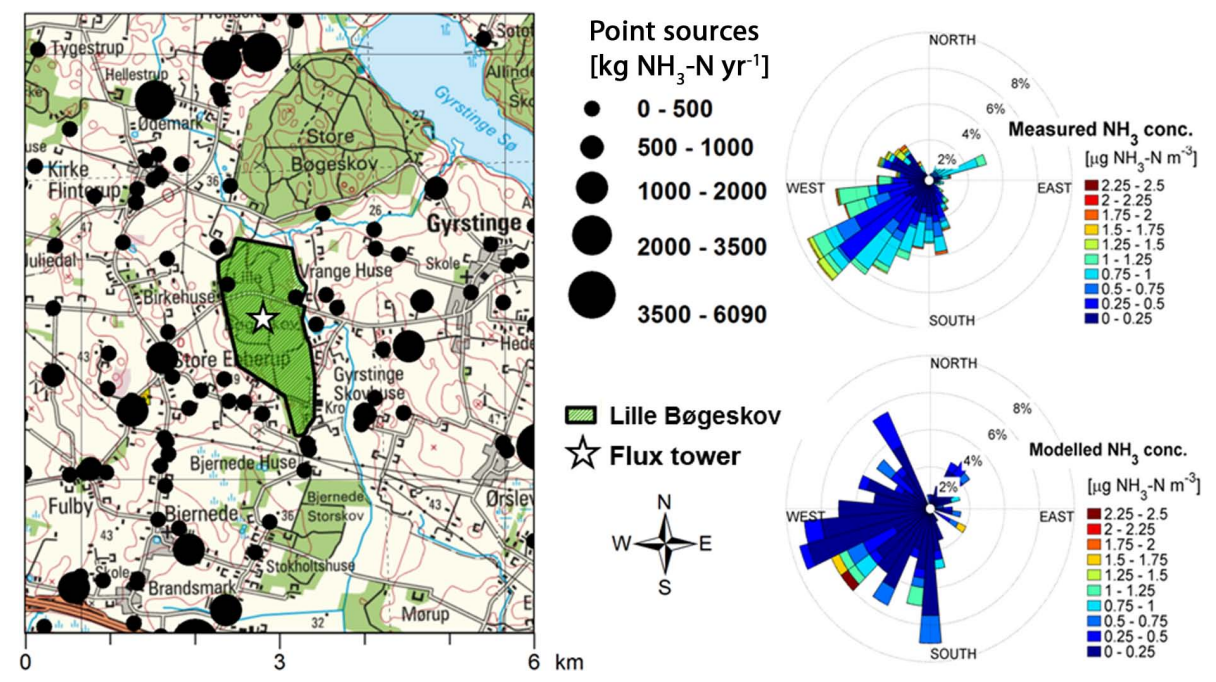

Fig. 4. $\mathrm{NH}_{3}$ emissions $\left(\mathrm{kg} \mathrm{NH}_{3}-\mathrm{N} \mathrm{yr}^{-1}\right)$ from point sources in 2008 (data are described in Sect. 2.6). The flux tower is marked with a white star in Lille Bøgeskov (the green scratched area). The concentration roses show measured concentration using REA (upper) and modelled concentration using DAMOS (lower) related to measured and simulated wind direction, respectively. Red colours indicate the highest assessed concentrations and blue indicate lowest concentrations.

Table 1. Statistics of the atmospheric ammonia $\left(\mathrm{NH}_{3}\right)$ flux measured $F_{\mathrm{NH}_{3}}$ above Lille Bøgeskov using relaxed eddy accumulation in $33 \mathrm{~m}$ and simulated using the two-layer bi-directional model $F_{\mathrm{t}}$ in the period 21 October to 15 November 2010.

\begin{tabular}{ccccc}
\hline & $\begin{array}{c}\text { Mean } \\
\left(\mu \mathrm{NH}_{3}-\mathrm{N} \mathrm{m}^{-2} \mathrm{~s}^{-1}\right)\end{array}$ & $\begin{array}{c}\text { Min } \\
\left(\mu \mathrm{g} \mathrm{N}_{3}-\mathrm{N} \mathrm{m}^{-2} \mathrm{~s}^{-1}\right)\end{array}$ & $\begin{array}{c}\text { Max } \\
\left(\mu \mathrm{NH}_{3}-\mathrm{N} \mathrm{m}^{-2} \mathrm{~s}^{-1}\right)\end{array}$ & $\begin{array}{c}\text { Stdev } \\
\left(\mu \mathrm{NH}_{3}-\mathrm{N} \mathrm{m}^{-2} \mathrm{~s}^{-1}\right)\end{array}$ \\
\hline$F_{\mathrm{NH}_{3}}$ & 0.06 & -0.25 & 0.67 & 0.15 \\
$F_{\mathrm{t}}$ & 0.07 & -0.03 & 0.47 & 0.11 \\
\hline
\end{tabular}

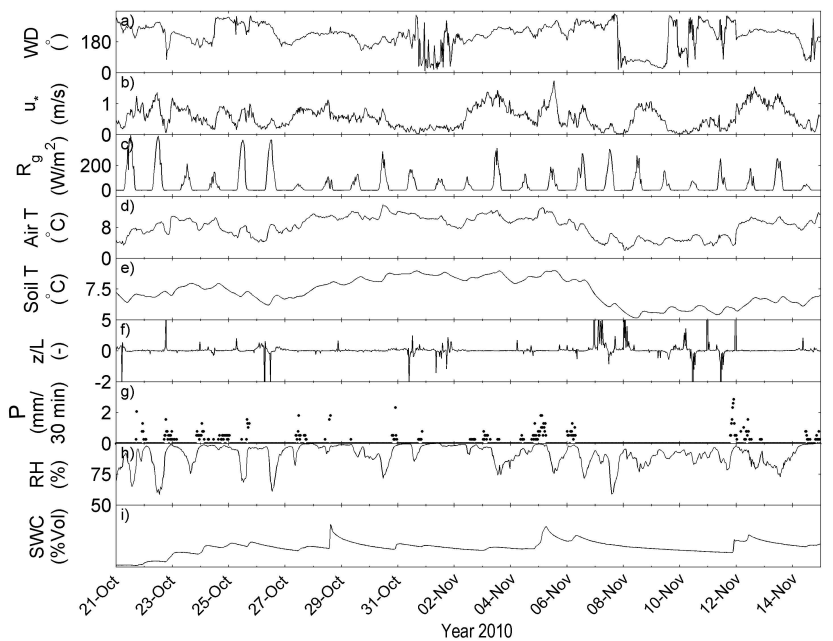

Fig. 5. Meteorological and soil measurements of (a) wind direction $\left[{ }^{\circ}\right]$, (b) friction velocity $\left[\mathrm{m} \mathrm{s}^{-1}\right]$, (c) global radiation $\left[\mathrm{W} \mathrm{m}^{-2}\right]$, (d) temperature $\left[{ }^{\circ} \mathrm{C}\right]$, (e) soil temperature $\left[{ }^{\circ} \mathrm{C}\right]$, (f) atmospheric stability $\left(\mathrm{z} \mathrm{L}^{-1}\right),(\mathrm{g})$ precipitation $[\mathrm{mm}],(\mathbf{h})$ relative humidity [\%] and (i) soil water content $[\%$ vol] for Lille Bøgeskov during the period 21 October to 15 November.

\subsection{Stomatal, cuticular and ground $\mathrm{NH}_{3}$ fluxes}

In Fig. 7 the forest component fluxes $F_{\mathrm{s}}, F_{\mathrm{w}}, F_{\mathrm{g}}$ and the total flux $F_{\mathrm{t}}$ simulated using the bi-directional $\mathrm{NH}_{3}$ compensation point model are illustrated together with the measured flux $F_{\mathrm{NH}_{3}}$. The dimensionless ratio $\Gamma_{\mathrm{g}}\left[\mathrm{NH}_{4}^{+} / \mathrm{H}^{+}\right]$was fitted to $F_{\mathrm{g}}$ and set to 300 before 30 October and to 80000 in the following period. A ratio of 80000 for $\Gamma_{\mathrm{g}}$ is extremely high, but still in the range of what has previously been found for fertilised grassland (Sutton et al., 2009). The bi-directional model was able to reproduce the temporal variations in the $\mathrm{NH}_{3}$ emissions following 30 October but underestimated the deposition fluxes by on average $75 \%$ (minimum $=6.27 \%$ and maximum $=99.89 \%$ ) before 30 October. Following 30 October, the simulated ground flux comprises most of the total flux $(142 \%)$, whereas stomatal and cuticular fluxes represent only $0.9 \%$ and $41 \%$ respectively.

\subsection{Observed ammonia concentrations}

Atmospheric $\mathrm{NH}_{3}$ concentrations measured by the REA system $\left(c_{\mathrm{RNH}_{3}}\right)$ varied from less than 0.03 to $2 \mu \mathrm{g} \mathrm{NH}_{3}-$ $\mathrm{N} \mathrm{m}^{-3}$ in the measurement period (Fig. 6b). The mean $c_{\mathrm{RNH}_{3}}$ was $0.56 \pm 0.35 \mu \mathrm{g} \mathrm{NH}_{3}-\mathrm{N} \mathrm{m}^{-3}$, and the detection 
limit was found to be $0.03 \mu \mathrm{g} \mathrm{NH}-\mathrm{N} \mathrm{m}^{-3}$. From 26 October

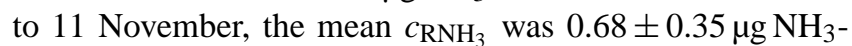
$\mathrm{N} \mathrm{m}^{-3}$, and the mean concentration obtained from denuder measurements $\left(c_{\mathrm{dNH}_{3}}\right)$ was $0.67 \pm 0.05 \mu \mathrm{g} \mathrm{NH}_{3}-\mathrm{N} \mathrm{m}^{-3}$ and above the detection limit (Table 2). A clear diurnal pattern was seen in $c_{\mathrm{RNH}_{3}}$ particularly in the beginning of the measurement period, which indicated increasing $c_{\mathrm{RNH}_{3}}$ at night and decreasing $c_{\mathrm{RNH}_{3}}$ during daytime (Fig. 6b). The concentration roses (Fig. 4) indicate that the dominating contribution of atmospheric $\mathrm{NH}_{3}$ originated from the southwest, where many smaller point sources were located, but the highest concentrations were related to northwesterly wind directions, where two $\mathrm{NH}_{3}$ point sources were located at the forest edge. Relatively low concentrations were seen when wind directions were from the northeast, where only few $\mathrm{NH}_{3}$ emission sources were located (Fig. 4).

\subsection{Simulated ammonia concentration using DAMOS}

Mean three-hourly modelled atmospheric concentrations by DAMOS $\left(c_{\mathrm{mNH}_{3}}\right)$ for the entire period (Fig. 6b) varied between $0.03 \pm 0.015$ and $2.51 \pm 1.255 \mu \mathrm{g} \mathrm{NH}_{3}-\mathrm{N} \mathrm{m}^{-3}$, and mean $c_{\mathrm{mNH}_{3}}$ was $0.50 \pm 0.25 \mu \mathrm{g} \mathrm{NH}_{3}-\mathrm{N} \mathrm{m}^{-3}$ (Table 2). It should be noted that the emission signal from the Danish area includes only point sources (stables and storage) as diffuse sources from agricultural areas are inactive in the period 1 October to 1 February due to Danish legislations on fertilisation management. This legislation on actual farming practice is dynamically incorporated in the $\mathrm{NH}_{3}$ emission model. Apart from five to six peaks exceeding $1 \mu \mathrm{g} \mathrm{NH}_{3}-\mathrm{N} \mathrm{m}^{-3}$, the simulated level of $c_{\mathrm{mNH}_{3}}$ remained between 0 and $1 \mu \mathrm{g} \mathrm{NH} \mathrm{N}_{3}$ $\mathrm{N} \mathrm{m}^{-3}$, and no decreasing or increasing trends were observed for the period. The $c_{\mathrm{mNH}_{3}}$ peaks exceeding $1 \mu \mathrm{g} \mathrm{NH} \mathrm{H}_{3}-\mathrm{N} \mathrm{m}^{-3}$ (Fig. 6b) were related mainly to contributions from local point sources located in the southwestern sector (Fig. 4) and to difficulties of the model in handling low friction velocities and changes in atmospheric stability.

\section{Discussion}

Despite the different measurement heights of REA (33 m) and the denuders $(29.8 \mathrm{~m})$, the mean atmospheric $\mathrm{NH}_{3}$ concentration measured for the period 26 October to 11 November 2010 are in good agreement, i.e. $0.68 \pm 0.35$ (REA) and $0.67 \pm 0.05$ (Denuder), and the simulated concentrations are also in a comparable range, i.e. $0.56 \pm 0.28 \mu \mathrm{g} \mathrm{NH} \mathrm{N}_{3}-\mathrm{N}$ (DAMOS) (Table 2). Even though we compare atmospheric measurements of $\mathrm{NH}_{3}$ concentration from two different measurement systems installed at two different heights separated by $3.2 \mathrm{~m}\left(c_{\mathrm{RNH}_{3}}\right.$ in $33 \mathrm{~m}$ and $c_{\mathrm{dNH}_{3}}$ in $\left.29.8 \mathrm{~m}\right)$, we expect that the measured concentrations are comparable due to the relatively high standard deviation on the concentrations measured by the REA system. Furthermore, the concentrations assessed are comparable with measurements for forests in

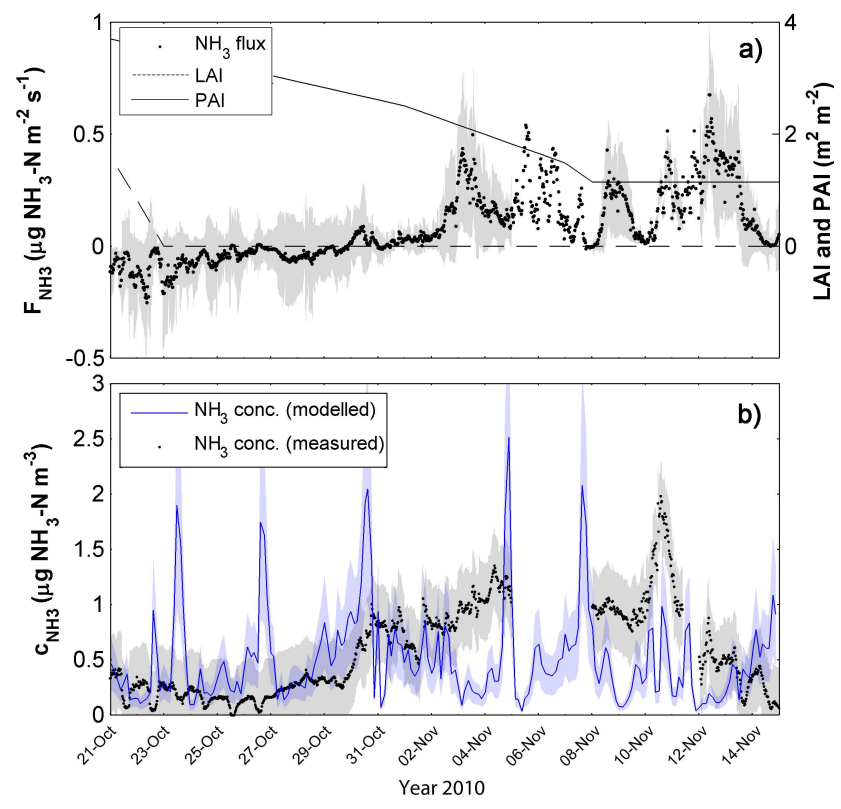

Fig. 6. Lille Bøgeskov in the period 21 October to 15 November 2010. (a) Half-hourly mean $\mathrm{NH}_{3}$ fluxes (black dots) measured using REA at $33 \mathrm{~m}$ height, leaf area index (LAI) (dashed line) and plant area index (PAI) (solid line). Grey shadings indicate the measurement uncertainty of the $\mathrm{NH}_{3}$ flux measurements. (b) Half-hourly mean $\mathrm{NH}_{3}$ concentrations (black dots) measured using REA and three-hourly mean $\mathrm{NH}_{3}$ concentrations modelled using DAMOS (blue line). Shadings indicate the measurement uncertainty and model uncertainties.

other Danish and US studies (Andersen et al., 1999; Pryor et al., 2001). Many studies have reported that forests generally act as efficient sinks taking up the atmospheric $\mathrm{NH}_{3}$ (i.e. Erisman and Wyers, 1993; Duyzer et al., 1994). In this study where leaf absorption of $\mathrm{NH}_{3}$ is almost non-existent due to leaf fall, $57.7 \%$ of the measured fluxes indicated emissions and $19.5 \%$ indicated depositions. The atmospheric ammonia flux measurements show a temporal correlation with the canopy's vegetation development (Fig. 6a and b), suggesting that $F_{\mathrm{NH}_{3}}$ decreases as LAI decreases, and that $\mathrm{NH}_{3}$ emissions occur in the leaf fall period. Apart from decomposition of litter, also natural emissions of $\mathrm{NH}_{3}$ linked to the leaf stomatal compensation point may cause $\mathrm{NH}_{3}$ emissions to increase in the senescent period (Wang et al., 2011, 2013). However such processes are not yet taken into account in the DAMOS system, and thus impacts of forest $\mathrm{NH}_{3}$ emissions are not represented in the $c_{\mathrm{NH}_{3}}$ model calculations. The relations between the $\mathrm{NH}_{3}$ fluxes and the vegetation status are discussed in the following along with the model performance.

\section{1 $\mathrm{LAI}$ and $\mathrm{NH}_{3}$ fluxes in the leaf fall period}

Before 30 October, the measured $c_{\mathrm{RNH}_{3}}$ was less than $0.5 \mu \mathrm{g} \mathrm{N}_{3}-\mathrm{N} \mathrm{m}^{-3}$, and during the leaf fall period 
Table 2. Statistics of the atmospheric ammonia $\left(\mathrm{NH}_{3}\right)$ concentration conducted using the relaxed eddy accumulation (REA) measurement technique $(33 \mathrm{~m})\left(c_{\mathrm{RNH}_{3}}\right)$, denuder measurements $(29.8 \mathrm{~m})\left(c_{\mathrm{dNH}_{3}}\right)$ and the DAMOS model $\left(c_{\mathrm{mNH}_{3}}\right)$ for Lille Bøgeskov in the period 26 October to 11 November 2010.

\begin{tabular}{lcccc}
\hline & $\begin{array}{c}\text { Mean } \\
\left(\mu \mathrm{g} \mathrm{NH}_{3}-\mathrm{N} \mathrm{m}^{-3}\right)\end{array}$ & $\begin{array}{c}\text { Min } \\
\left(\mu \mathrm{g} \mathrm{N}_{3}-\mathrm{N} \mathrm{m}^{-3}\right)\end{array}$ & $\begin{array}{c}\text { Max } \\
\left(\mu \mathrm{g} \mathrm{N}_{3}-\mathrm{N} \mathrm{m}^{-3}\right)\end{array}$ & $\begin{array}{c}\text { Stdev } \\
\left(\mu \mathrm{g} \mathrm{N}_{3}-\mathrm{N} \mathrm{m}^{-3}\right)\end{array}$ \\
\hline$c_{\mathrm{RNH}_{3} \text { (REA) }}$ (Denuder) & 0.68 & 0 & 1.98 & 0.40 \\
$c_{\mathrm{dNH}_{3}}$ (DAMOS) & 0.67 & - & - & - \\
$c_{\mathrm{mNH}_{3}}$ & 0.56 & 0.03 & 2.51 & 0.45 \\
\hline
\end{tabular}

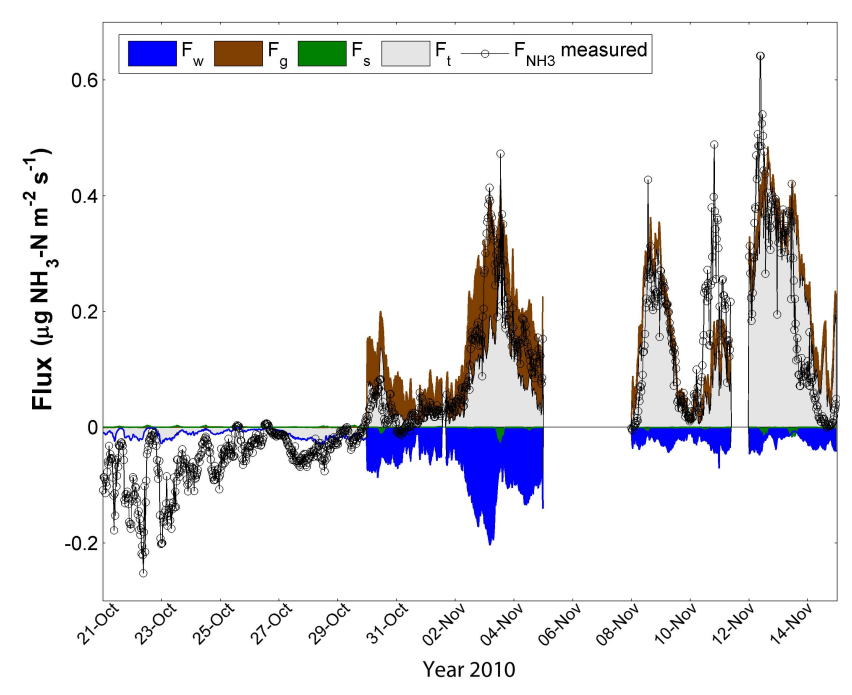

Fig. 7. Simulations of the forest component half-hourly fluxes in Lille Bøgeskov in the period 21 October to 15 November 2010. Blue shading shows cuticular flux $\left(F_{\mathrm{W}}\right)$, brown shading shows ground flux $\left(F_{\mathrm{g}}\right)$, green shading shows stomatal flux $\left(F_{\mathrm{S}}\right)$, grey shading shows the total flux $\left(F_{\mathrm{t}}=F_{\mathrm{W}}+F_{\mathrm{g}}+F_{\mathrm{S}}\right)$, and the open circles with error bars indicate the measured flux $F_{\mathrm{NH}_{3}}$ and the measurement uncertainty.

(23 October to 8 November) a clear increase in the $c_{\mathrm{RNH}_{3}}$ was seen (Fig. 6b). After 30 October, the $c_{\mathrm{RNH}_{3}}$ level was typically higher than the mean $\left(0.56 \pm 0.35 \mu \mathrm{g} \mathrm{NH}_{3}-\mathrm{N} \mathrm{m}^{-3}\right)$ for the measurement period. This increase was found to be related to the increasing forest $\mathrm{NH}_{3}$ flux that was observed after 2 November (Fig. 6a). The modelled concentration $c_{\mathrm{mNH}_{3}}$ did not show such an increase in the same period, indicating that a natural source, the forest, was causing the increase in $c_{\mathrm{RNH}_{3}}$. As defoliation ended, $F_{\mathrm{NH}_{3}}$ turned positive and changed from showing net deposition to net emissions of $\mathrm{NH}_{3}$ following the leaf fall period. The increased emissions could be due to a combination of increased litter emissions and decreased leaf absorption, but also to changes in the turbulent transfer above the canopy related to the leaf fall. During and after the leaf all period, four evident $\mathrm{NH}_{3}$ emission peaks (on 2-4, 8/9, 10/11 and 12-14 November) occurred (Fig. 6a), and clear relations to the friction velocity (Fig. 5b) are seen for all four peak emissions, indicating that the turbu- lent flow above the forest canopy controls a large part of the emission flux. Other than the friction velocity, no clear control pattern of other environmental or climatic conditions is seen that can explain the emission events. However, as precipitation occurred during most of the period (Fig. 5g), the emissions can also be caused by volatilisation of $\mathrm{NH}_{3}$ from moist soil and wet leaves, as suggested by Pryor et al. (2001). The emissions found on 2-4 November and 12-14 November were related to precipitation events followed by dry periods with relatively high air temperatures. Such conditions enhance the decomposition process of plant material and may explain the emissions on these occasions. Such conditions were not present on 8/9 November and 10/11 November, when peak emissions were also measured. Studies based on dynamic chamber techniques and within-canopy profile measurements of the $\mathrm{NH}_{3}$ flux have reported $\mathrm{NH}_{3}$ emissions from intensively managed ecosystems, and suggest reemission from senescent leaves and decomposition of leaf litter to be a strong source of $\mathrm{NH}_{3}$ emissions, particularly in humid conditions (David et al., 2009; Nemitz et al., 2000a). The emission potential for senescent leaves or leaf litter of grassland was studied in the GRAMINAE Integrated Experiment (Sutton et al., 2009) and reported by David et al. (2009), who found that the emission potential was a hundred times larger than that of green leaves, and that emissions were larger when the litter was moisturised than when dry. Soil conditions such as temperature, moisture, $\mathrm{pH}$, and nitrogen content have also been found to be controlling factors for the $\mathrm{NH}_{3}$ emissions (Riedo et al., 2002; Roelle and Aneja, 2002; Walker et al., 2013), however, not as crucial as the leaf litter. Despite the low $\mathrm{pH}$ of the soils in Lille Bøgeskov, the conditions for decomposition are relatively good, and volatilisation of $\mathrm{NH}_{3}$ due to the microbiological breakdown of organic material could occur. However, we are aware that the observed $\mathrm{NH}_{3}$ emissions are measured during relatively low air and soil temperatures (below $10^{\circ} \mathrm{C}$ ) that slow down the decomposition processes.

The forest component fluxes from the bi-directional $\mathrm{NH}_{3}$ compensation point model indicated high emission fluxes from the ground layer following 30 October correlated to the atmospheric $\mathrm{NH}_{3}$ emissions. The decreased deposition in the senescence period could also be caused by reduced leaf uptake of $\mathrm{NH}_{3}$ through stomata, decreased cuticular 
desorption and larger $\mathrm{NH}_{3}$ emission potential of the senescent leaves related to remobilisation of nitrogen during leaf senescence (Wang et al., 2011, 2013). The bi-directional model showed a slightly decreased cuticular flux $F_{\mathrm{w}}$ (Fig. 7) during senescence (21/30 October), however, no significant effect of stomatal control of the $\mathrm{NH}_{3}$ flux. The model underestimated the deposition flux by on average $75 \%$ before 30 October and suggested cuticular deposition to be the controlling process, while the stomatal flux was nearly non-existent (emissions up to $0.003 \mu \mathrm{g} \mathrm{NH}_{3}-\mathrm{N} \mathrm{m}^{-2} \mathrm{~s}^{-1}$ ). Assuming that the maximum possible flux permitted by turbulent transport can be calculated as $F_{\mathrm{Max}}=-c_{\mathrm{NH}_{3}} / R_{\mathrm{a}}$, the measured deposition flux in the period 21-30 October is much larger than $F_{\text {Max }}$. However, the $F_{\text {Max }}$ parameterisation is based on the assumptions of horizontal and vertical homogeneity, and no chemical reactions must occur within the gradient. It has earlier been found that these assumptions were violated for $\mathrm{NH}_{3}$ exchange between surfaces and the atmosphere (Sorensen et al., 2003; Duyzer et al., 1994). Furthermore, due to the uncertainty of the measurements in the period 21-30 October $\left( \pm 0.14 \mu \mathrm{g} \mathrm{NH} \mathrm{N}_{3}-\mathrm{N}^{-1}\right)$, the deposition flux measured could just as well be less than $F_{\text {Max }}$.

Following leaf fall, the magnitude and temporal structure of the measured $\mathrm{NH}_{3}$ emission fluxes could be adequately reproduced with the bi-directional resistance model. The magnitude was achieved by using a $\Gamma_{\mathrm{g}}$ value of 80000 following leaf fall, which is in the range of values found for senescing plant material (e.g. Sutton et al., 2009), but larger than measurements of the litter emission potential established by Wang et al. (2011) during the previous autumn. In the absence of in-canopy turbulence measurements, the parameterisation of the in-canopy transport resistance is poorly constrained. Any scaling error in this resistance would result in a similar scaling error of $\Gamma_{\mathrm{g}}$. Because a constant value of $\Gamma_{\mathrm{g}}$ is used after leaf fall, the temporal variability in the model result is dominated by the variability in $\mathrm{u}_{*}$, on which the parameterisation of in-canopy resistance is based. The results demonstrate that the emissions are consistent with a source inside the canopy, the connection of which to the atmosphere is regulated by turbulence. A minor fraction of the $\mathrm{NH}_{3}$ emitted from the leaf litter at ground level is predicted to be recaptured by the surfaces of the tree canopy $\left(F_{\mathrm{w}}\right)$, and this fraction decreases as the PAI decreases. The model underestimates the net flux on 10 November and overestimates the flux on 13/14 November. The first period is at the end of a drying period and during very low turbulence when convective processes contribute to in-canopy transport that would be underestimated by a $u_{*}$-based parameterisation. Alternatively, the re-establishment of good agreement on 12 November follows a precipitation event, and this might indicate that a secondary effect of moisture on the mineralisation and thus emission rate further modulates the emission of the ground surface.

\subsection{OML-DEP model results}

The simulated $\mathrm{NH}_{3}$ concentration level in the senescent period fitted well the measured concentrations, but the modelled concentrations were too low following leaf fall (Fig. 6b). On 10 November the measured $c_{\mathrm{RNH}_{3}}$ increased rapidly up to $1.98 \mu \mathrm{g} \mathrm{NH}_{3}-\mathrm{N} \mathrm{m}^{-3}$, caused by the forest $\mathrm{NH}_{3}$ emission, while the modelled $c_{\mathrm{mNH}_{3}}$ showed two narrow peaks that were related to changes in the atmospheric stability from the meteorological input to the model. $c_{\mathrm{RNH}_{3}}$ was twice the magnitude of $c_{\mathrm{mNH}_{3}}$ in this period, indicating that the missing contribution to $c_{\mathrm{NH}_{3}}$ from the forest is of a relatively large magnitude and therefore important to study and also include in model calculations.

Inadequate descriptions of surface properties such as aerodynamic roughness, stomatal resistance and processes related to the bi-directionality of atmospheric $\mathrm{NH}_{3}$ fluxes represent uncertainties in current biosphere-atmosphere exchange modelling of $\mathrm{NH}_{3}$ (Simpson et al., 2011). The complex mechanisms controlling these exchange processes cause current model parameterisations of biological and chemical pathways and processes to be empirical and based on few existing datasets (Flechard et al., 2011; Menut and Bessagnet, 2010; Pouliot et al., 2012). In DAMOS, the deposition is calculated for various land use categories and the surface resistance is divided into stomatal and non-stomatal components. For $\mathrm{NH}_{3}$ the non-stomatal component includes, among other things, an acidity ratio between $\mathrm{SO}_{2}$ and $\mathrm{NH}_{3}$ (Emberson et al., 2000; Simpson et al., 2003), while a stomatal compensation point is not included. Many on-going studies explore methods to include these processes in models to calculate the $\mathrm{NH}_{3}$ exchange between vegetative surfaces and the atmosphere (Wichink Kruit et al., 2012; Massad et al., 2010). Riedo et al. (2002) coupled a two-layer resistance model to a $\mathrm{NH}_{3}$ exchange model to include ecosystem $\mathrm{N}$ dynamics for an intensively managed grassland. The model, PaSim, was able to simulate effects of cutting and fertilisation, but postulated that leaf litter was the reason for underestimation of $\mathrm{NH}_{3}$ emission peaks. Other modelling concepts simulated leaf $\mathrm{NH}_{3}$ emissions by including the stomatal compensation point and a litter layer with the emission potential, $\Gamma$, being dependent on the relative air humidity (Nemitz et al., 2000b). Bi-directional approaches for simulating ammonia emissions are being developed for several chemistry transport models (CTMs) such as the CMAQ, DEHM, EMEP, CHIMERE, and LOTUS-EUROS models (Aas et al., 2012; Skjøth et al., 2011; Cooter et al., 2012; Hamaoui-Laguel et al., 2012). Here, calculations of the ammonia emissions as a function of ambient conditions are expected to improve calculations and understanding considerably (e.g. Hendriks et al., 2013). But to our knowledge, these methods do not include ammonia emissions from litter fall from forest. Further experiments conducting ground layer and canopy layer information of the stomatal and ground layer emission potential, 
$\Gamma$, are necessary to develop new parameterisations to forestatmosphere exchange of $\mathrm{NH}_{3}$.

Despite these efforts, we are still lacking knowledge of most biosphere-atmosphere exchange processes of $\mathrm{N}$ compounds (including potential feedback mechanisms) (Arneth et al., 2010). Flux studies in combination with model calculations are therefore needed in order to highlight the knowledge gaps and target future model improvements.

\subsection{Diurnal dynamics in atmospheric ammonia concentration}

Measured $c_{\mathrm{RNH}_{3}}$ indicated a clear diurnal pattern in the beginning of the measurement period with increased concentrations during night and decreased concentrations during day, showing that $c_{\mathrm{NH}_{3}}$ varied significantly over shorter timescales (Fig. 6b). Stable atmospheric conditions during nighttime suppress the mixing of air and reduce the atmospheric boundary layer height, thereby leading to higher $\mathrm{NH}_{3}$ concentrations in the lower atmosphere. The model only captured these diurnal variations to a small extent (24-26 October) before defoliation ended, and it even showed anticorrelations for the three days 21-24 October. It is known that Gaussian models including OML have problems when meteorological conditions change from stable to unstable and low friction velocities prevail (Olesen et al., 2007). One of the main problems is that the Gaussian formulation assumes stationary conditions during the calculation period, which is not appropriate under certain conditions such as low wind speeds (see full discussion in Olesen et al., 2007). In the current study, the comparison with high-resolution measurements showed that the observed diurnal variation $c_{\mathrm{RNH}_{3}}$ is hard to capture by the model. Some of the conceptual limitations can be improved with more advanced parameterisations such as updating the description of horizontal dispersion in OML. Other limitations require the Gaussian OML to be replaced with more advanced models (Olesen et al., 2007). The lower performance of OML during these few and special meteorological conditions does not affect the main conclusions: that there is a need to represent $\mathrm{NH}_{3}$ releases from natural ecosystems, such as forests during leaf fall, for accurate highspatial and high-temporal (diurnal) atmospheric simulation of $c_{\mathrm{NH}_{3}}$. Therefore, more data on $\mathrm{NH}_{3}$ fluxes are necessary to improve our understanding of controlling parameters in the biosphere-atmosphere $\mathrm{NH}_{3}$ exchange processes.

\section{Conclusions}

Measurements in a deciduous beech forest showed that $F_{\mathrm{NH}_{3}}$ changed from negative (deposition) to positive (emission) fluxes during the leaf fall period 21 October to 15 November 2010, causing increased atmospheric $\mathrm{NH}_{3}$ concentration. This change was temporally correlated to the vegetation status of the forest. The observations of
LAI and PAI showed that the period with increased $c_{\mathrm{RNH}_{3}}$ was in the leaf fall period, and peak emissions up to $0.67 \pm 0.28 \mu \mathrm{g} \mathrm{NH}_{3}-\mathrm{N} \mathrm{m}^{-2} \mathrm{~s}^{-1}$ were observed. The simple two-layer bi-directional canopy compensation model was able to adequately reproduce the magnitude and temporal structure of the measured $\mathrm{NH}_{3}$ emission fluxes following leaf fall and indicated that the forest ground layer (soil and litter) acted as the main contributing component to the $\mathrm{NH}_{3}$ emissions. The mean $\mathrm{NH}_{3}$ concentrations were well simulated using DAMOS before leaf fall, but were underestimated following leaf fall. This points to the need for representing forest leaf fall and associated $\mathrm{NH}_{3}$ emissions in chemical transport models when simulating nitrogen deposition to forests. Besides influence on the atmosphere-forest exchange of $\mathrm{NH}_{3}$ from the forest's phenology, variations in meteorological and soil conditions, and the canopy turbulence, our observations support the hypothesis that $\mathrm{NH}_{3}$ emissions occur from deciduous forests in relation to leaf fall possibly due to increased litter emissions or decreased leaf absorption or a combination of these. Additionally, diurnal variations of $c_{\mathrm{RNH}_{3}}$ related to meteorological conditions (i.e. radiation control on stomatal resistance), forest phenology (i.e. LAI), and the spatial distribution of local anthropogenic $\mathrm{NH}_{3}$ sources were found. This suggests that dedicated process studies including manipulation of ecosystems would be very valuable for improved understanding of $\mathrm{NH}_{3}$ fluxes from natural vegetation. Despite large uncertainties associated with the results obtained in this study due to the assessment techniques and the limited dataset, the good agreement between $c_{\mathrm{dNH}_{3}}$, $c_{\mathrm{RNH}_{3}}$ and $c_{\mathrm{mNH}_{3}}$ gives confidence in the data. The results must be considered as a good contribution to improve our understanding of the processes related to natural $\mathrm{NH}_{3}$ emissions. This knowledge can be used in direct ecosystem manipulation studies or model studies in order to quantify the $\mathrm{NH}_{3}$ emission flux from ecosystems and the total biosphereatmosphere net flux of reactive nitrogen.

Acknowledgements. This study was conducted within NitroEurope IP (project no: 0174841-2). Additionally, the ECOCLIM project funded by the Danish Strategic Research Council supported this study with a $\mathrm{PhD}$ grant to Kristina Hansen and the EU project ECLAIRE (project no: 282910) and the Villum-Kann Rasmussen Foundation through a postdoc grant to Carsten Ambelas Skjøth. We gratefully acknowledge Helle V. Andersen and Christina F. Emborg (Dept. of Environmental Science, Aarhus University) for their making the chemical analyses of the denuder measurements, Søren Lund (Dept. of Wind Energy, Technical University Denmark) and Morten K. Hildan (Dept. of Environmental Science, Aarhus University) for technical support, Ebba Dellwik (Dept. of Wind Energy, Technical University Denmark) and Andreas Ibrom (Dept. of Chemical and Biochemical Engineering, Technical University Denmark) for additionally providing us data from the field station for the analysis, and finally the editor Eiko Nemitz for constructive support.

Edited by: E. Nemitz 


\section{References}

Aas, W., Tsyro, S., Bieber, E., Bergström, R., Ceburnis, D., Ellermann, T., Fagerli, H., Frölich, M., Gehrig, R., Makkonen, U., Nemitz, E., Otjes, R., Perez, N., Perrino, C., Prévôt, A. S. H., Putaud, J.-P., Simpson, D., Spindler, G., Vana, M., and Yttri, K. E.: Lessons learnt from the first EMEP intensive measurement periods, Atmos. Chem. Phys., 12, 8073-8094, doi:10.5194/acp12-8073-2012, 2012.

Andersen, H. V., Hovmand, M. F., Hummelshøj, P., and Jensen, N. O.: Measurements of ammonia concentrations, fluxes and dry deposition velocities to a spruce forest 1991-1995, Atmos. Environ., 33, 1367-1383, doi:10.1016/S1352-2310(98)00363-X, 1999.

Arneth, A., Harrison, S. P., Zaehle, S., Tsigaridis, K., Menon, S., Bartlein, P. J., Feichter, J., Korhola, A., Kulmala, M., O’Donnell, D., Schurgers, G., Sorvari, S., and Vesala, T.: Terrestrial biogeochemical feedbacks in the climate system, Nat. Geosci., 3, 525532, doi:10.1038/ngeo905, 2010.

Barrett, K.: Oceanic ammonia emissions in Europe and their transboundary fluxes, Atmos. Environ., 32, 381-391, doi:10.1016/S1352-2310(97)00279-3, 1998.

Bartnicki, J., Semeena, V. S., and Fagerli, H.: Atmospheric deposition of nitrogen to the Baltic Sea in the period 1995-2006, Atmos. Chem. Phys., 11, 10057-10069, doi:10.5194/acp-1110057-2011, 2011.

Bobbink, R., Hicks, K., Galloway, J., Spranger, T., Alkemade, R., Ashmore, M., Bustamante, M., Cinderby, S., Davidson, E., Dentener, F., Emmett, B., Erisman, J.-W., Fenn, M., Gilliam, F., Nordin, A., Pardo, L., and De Vries, W.: Global assessment of nitrogen deposition effects on terrestrial plant diversity: a synthesis, Ecol. Appl., 20, 30-59, doi:10.1890/08-1140.1, 2010.

Bouwman, A., Lee, D., Asman, W., Dentener, F., VanderHoek, K., and Olivier, J.: A global high-resolution emission inventory for ammonia, Global Biochem. Cy., 11, 561-587, doi:10.1029/97GB02266, 1997.

Brandt, J., Silver, J. D., Frohn, L. M., Geels, C., Gross, A., Hansen, A. B., Hansen, K. H., Hedegaard, G. B., Skjøth, C. A., Villadsen, H., Zare, A., and Christensen, J. H.: An integrated model study for Europe and North America using the Danish Eulerian Hemispheric Model with focus on intercontinental transport of air pollution, Atmos. Environ., 53, 156-176, doi:10.1016/j.atmosenv.2012.01.011, 2012.

Businger, J. A. and Oncley, S. P.: Flux Measurement with Conditional Sampling, J. Atmos. Ocean. Tech., 7, 349-352, 1990.

Christensen, J. H.: The Danish Eulerian hemispheric model - A three-dimensional air pollution model used for the Arctic, Atmos. Environ., 31, 4169-4191, doi:10.1016/S13522310(97)00264-1, 1997.

Cooter, E. J., Bash, J. O., Benson, V., and Ran, L.: Linking agricultural crop management and air quality models for regional to national-scale nitrogen assessments, Biogeosciences, 9, 40234035, doi:10.5194/bg-9-4023-2012, 2012.

David, M., Loubet, B., Cellier, P., Mattsson, M., Schjoerring, J. K., Nemitz, E., Roche, R., Riedo, M., and Sutton, M. A.: Ammonia sources and sinks in an intensively managed grassland canopy, Biogeosciences, 6, 1903-1915, doi:10.5194/bg-6-19032009, 2009.

de Leeuw, G., Spokes, L., Jickells, T., Skjoth, C., Hertel, O., Vignati, E., Tamm, S., Schulz, M., Sorensen, L., Pedersen, B., Klein, L., and Schlunzen, K.: Atmospheric nitrogen inputs into the North Sea: effect on productivity, Cont. Shelf Res., 23, 1743-1755, doi:10.1016/j.csr.2003.06.011, 2003.

de Vries, W., Solberg, S., Dobbertin, M., Sterba, H., Laubhann, D., van Oijen, M., Evans, C., Gundersen, P., Kros, J., Wamelink, G. W. W., Reinds, G. J., and Sutton, M. A.: The impact of nitrogen deposition on carbon sequestration by European forests and heathlands RID F-2087-2010 RID B-2192-2008, Forest Ecol. Manag., 258, 1814-1823, doi:10.1016/j.foreco.2009.02.034, 2009.

Duce, R. A., LaRoche, J., Altieri, K., Arrigo, K. R., Baker, A. R., Capone, D. G., Cornell, S., Dentener, F., Galloway, J., Ganeshram, R. S., Geider, R. J., Jickells, T., Kuypers, M. M., Langlois, R., Liss, P. S., Liu, S. M., Middelburg, J. J., Moore, C. M., Nickovic, S., Oschlies, A., Pedersen, T., Prospero, J., Schlitzer, R., Seitzinger, S., Sorensen, L. L., Uematsu, M., Ulloa, O., Voss, M., Ward, B., and Zamora, L.: Impacts of atmospheric anthropogenic nitrogen on the open ocean, Science, 320, 893-897, doi:10.1126/science.1150369, 2008.

Duyzer, J., Verhagen, H. L. M., Weststrate, J. H., Bosveld, F. C., and Vermetten, A. W. M.: The Dry Deposition of Ammonia Onto A Douglas-Fir Forest in the Netherlands, Atmos. Environ., 28, 1241-1253, doi:10.1016/1352-2310(94)90271-2, 1994.

Emberson, L. D., Ashmore, M. R., Cambridge, H. M., Simpson, D., and Tuovinen, J. P.: Modelling stomatal ozone flux across Europe, Environ. Pollut., 109, 403-413, doi:10.1016/S02697491(00)00043-9, 2000.

Erisman, J. W. and Wyers, G. P.: Continuous Measurements of Surface Exchange of So(2) and Nh(3) - Implications for Their Possible Interaction in the Deposition Process, Atmos. Environ. A-Gen., 27, 1937-1949, doi:10.1016/0960-1686(93)902662, 1993.

Erisman, J. W., Bleeker, A., Galloway, J., and Sutton, M. S.: Reduced nitrogen in ecology and the environment, Environ. Pollut., 150, 140-149, doi:10.1016/j.envpol.2007.06.033, 2007.

Ferm, M.: Method for determination of atmospheric ammonia, Atmos. Environ., 13, 1385-1391, 1979.

Flechard, C. R., Nemitz, E., Smith, R. I., Fowler, D., Vermeulen, A. T., Bleeker, A., Erisman, J. W., Simpson, D., Zhang, L., Tang, Y. S., and Sutton, M. A.: Dry deposition of reactive nitrogen to European ecosystems: a comparison of inferential models across the NitroEurope network, Atmos. Chem. Phys., 11, 2703-2728, doi:10.5194/acp-11-2703-2011, 2011.

Gao, W.: The vertical change of coefficient b, used in the relaxed eddy accumulation method for flux measurement above and within a forest canopy, Atmos. Environ., 29, 2339-2347, doi:10.1016/1352-2310(95)00147-Q, 1995.

Geels, C., Hansen, K. M., Christensen, J. H., Ambelas Skjøth, C., Ellermann, T., Hedegaard, G. B., Hertel, O., Frohn, L. M., Gross, A., and Brandt, J.: Projected change in atmospheric nitrogen deposition to the Baltic Sea towards 2020, Atmos. Chem. Phys., 12, 2615-2629, doi:10.5194/acp-12-2615-2012, 2012a.

Geels, C., Andersen, H. V., Ambelas Skjøth, C., Christensen, J. H., Ellermann, T., Løfstrøm, P., Gyldenkærne, S., Brandt, J., Hansen, K. M., Frohn, L. M., and Hertel, O.: Improved modelling of atmospheric ammonia over Denmark using the coupled modelling system DAMOS, Biogeosciences, 9, 2625-2647, doi:10.5194/bg-9-2625-2012, 2012b. 
Gyldenkærne, S., Skjøth, C. A., Hertel, O., and Ellermann, T.: A dynamical ammonia emission parameterization for use in air pollution models, J. Geophys. Res.-Atmos., 110, D07108, doi:10.1029/2004JD005459, 2005.

Hamaoui-Laguel, L., Meleux, F., Beekmann, M., Bessagnet, B., Genermont, S., Cellier, P., and Letinois, L.: Improving ammonia emissions in air quality modelling for France, Atmos. Environ., doi:10.1016/j.atmosenv.2012.08.002, in press, 2012.

Hendriks, C., Kranenburg, R., Kuenen, J., van Gijlswijk, R., Wichink Kruit, R., Segers, A., Denier van der Gon, H., and Schaap, M.: The origin of ambient particulate matter concentrations in the Netherlands, Atmos. Environ., 69, 289-303, 2013.

Hensen, A., Nemitz, E., Flynn, M. J., Blatter, A., Jones, S. K., Sørensen, L. L., Hensen, B., Pryor, S. C., Jensen, B., Otjes, R. P., Cobussen, J., Loubet, B., Erisman, J. W., Gallagher, M. W., Neftel, A., and Sutton, M. A.: Inter-comparison of ammonia fluxes obtained using the Relaxed Eddy Accumulation technique, Biogeosciences, 6, 2575-2588, doi:10.5194/bg-6-2575-2009, 2009.

Hertel, O., Ambelas Skjøth, C., Brandt, J., Christensen, J. H., Frohn, L. M., and Frydendall, J.: Operational mapping of atmospheric nitrogen deposition to the Baltic Sea, Atmos. Chem. Phys., 3, 2083-2099, doi:10.5194/acp-3-2083-2003, 2003.

Hertel, O., Skjøth, C. A., Reis, S., Bleeker, A., Harrison, R. M., Cape, J. N., Fowler, D., Skiba, U., Simpson, D., Jickells, T., Kulmala, M., Gyldenkærne, S., Sørensen, L. L., Erisman, J. W., and Sutton, M. A.: Governing processes for reactive nitrogen compounds in the European atmosphere, Biogeosciences, 9, 49214954, doi:10.5194/bg-9-4921-2012, 2012.

Hertel, O., Geels, C., Frohn, L. M., Ellermann, T., Skjøth, C. A., Løfstrøm, P., Christensen, J. H., Andersen, H. V., and Peel, R. G.: Assessing atmospheric nitrogen deposition to natural and semi-natural ecosystems e Experience from Danish studies using the DAMOS, Atmos. Environ., 66, 151-160, doi:10.1016/j.atmosenv.2012.02.071, 2013.

Hicks, B. B. and Mcmillen, R. T.: A Simulation of the Eddy Accumulation Method for Measuring Pollutant Fluxes, J. Clim. Appl. Meteorol., 23, 637-643, doi:10.1175/15200450(1984)023<0637:ASOTEA > 2.0.CO;2, 1984.

Langner, J., Andersson, C., and Engardt, M.: Atmospheric input of nitrogen to the Baltic Sea basin: present situation, variability due to meteorology and impact of climate change, Boreal Environ. Res., 14, 226-237, 2009.

Massad, R.-S., Nemitz, E., and Sutton, M. A.: Review and parameterisation of bi-directional ammonia exchange between vegetation and the atmosphere, Atmos. Chem. Phys., 10, 10359-10386, doi:10.5194/acp-10-10359-2010, 2010.

Mattsson, M., Herrmann, B., David, M., Loubet, B., Riedo, M., Theobald, M. R., Sutton, M. A., Bruhn, D., Neftel, A., and Schjoerring, J. K.: Temporal variability in bioassays of the stomatal ammonia compensation point in relation to plant and soil nitrogen parameters in intensively managed grassland, Biogeosciences, 6, 171-179, doi:10.5194/bg-6-171-2009, 2009.

Menut, L. and Bessagnet, B.: Atmospheric composition forecasting in Europe, Ann. Geophys., 28, 61-74, doi:10.5194/angeo-28-612010, 2010.

Nemitz, E., Milford, C., and Sutton, M. A.: A two-layer canopy compensation point model for describing bi-directional biosphere-atmosphere exchange of ammonia, Q. J. Roy. Meteorol. Soc., 127, 815-833, doi:10.1256/smsqj.57305, 2001.
Nemitz, E., Sutton, M., Gut, A., San Jose, R., Husted, S., and Schjoerring, J.: Sources and sinks of ammonia within an oilseed rape canopy, Agr. Forest Meteorol., 105, 385-404, doi:10.1016/S0168-1923(00)00205-7, 2000a.

Nemitz, E., Sutton, M., Schjoerring, J., Husted, S., and Wyers, G.: Resistance modelling of ammonia exchange over oilseed rape, Agr. Forest Meteorol., 105, 405-425, doi:10.1016/S01681923(00)00206-9, 2000b.

Nielsen, K., Stjernholm, M., Olsen, B. O., Müller-Wohlfeil, D., Madsen, I. K. A., Groom, G., Hansen, H. S., Rolev, A. M., Hermansen, B., Skov-Petersen, H., Johannsen, V. K., Hvidberg, M., Jensen, J. E., Bacher, V., and Larsen, H.: Areal Informations Systemet - AIS, Technical report, 112 pp., Danish Ministry of Environment, Denmark, 2000.

Olesen, H. R., Berkowicz, R. B., and Løfstrøm, P.: OML: Review of model formulation, Technical Report No. 609, 130 pp., National Environmental Research Institute, Denmark, NERI, 2007.

Oncley, S. P., Delany, A. C., Horst, T. W., and Tans, P. P.: Verification of Flux Measurement Using Relaxed Eddy Accumulation, Atmos. Environ. A-Gen., 27, 2417-2426, 1993.

Østergård, J.: Jordbundsdannelse under bøgeskov og mark ved Lille Bøgeskov, Sorø, Master's thesis, 130 pp., Department of Earth Sciences, University of Aarhus, Denmark, 2000 (in Danish).

Pilegaard, K., Ibrom, A., Courtney, M. S., Hummelshoj, P., and Jensen, N. O.: Increasing net $\mathrm{CO}(2)$ uptake by a Danish beech forest during the period from 1996 to 2009 , RID A-9850-2011, Agr. Forest Meteorol., 151, 934-946, doi:10.1016/j.agrformet.2011.02.013, 2011.

Pouliot, G., Pierce, T., van der Gon, H. D., Schaap, M., Moran, M., and Nopmongcol, U.: Comparing emission inventories and model-ready emission datasets between Europe and North America for the AQMEII project, Atmos. Environ., 53, 4-14, doi:10.1016/j.atmosenv.2011.12.041, 2012.

Pryor, S. C., Barthelmie, R. J., Sorensen, L. L., and Jensen, B.: Ammonia concentrations and fluxes over a forest in the midwestern USA, Atmos. Environ., 35, 5645-5656, doi:10.1016/S13522310(01)00259-X, 2001.

Reis, S., Pinder, R. W., Zhang, M., Lijie, G., and Sutton, M. A.: Reactive nitrogen in atmospheric emission inventories, Atmos. Chem. Phys., 9, 7657-7677, doi:10.5194/acp-9-7657-2009, 2009.

Ren, X., Sanders, J. E., Rajendran, A., Weber, R. J., Goldstein, A. H., Pusede, S. E., Browne, E. C., Min, K.-E., and Cohen, R. C.: A relaxed eddy accumulation system for measuring vertical fluxes of nitrous acid, Atmos. Meas. Tech., 4, 2093-2103, doi:10.5194/amt-4-2093-2011, 2011.

Riedo, M., Milford, C., Schmid, M., and Sutton, M.: Coupling soil-plant-atmosphere exchange of ammonia with ecosystem functioning in grasslands, Ecol. Model., 158, 83-110, doi:10.1016/S0304-3800(02)00169-2, 2002.

Roelle, P. A. and Aneja, V. P.: Characterization of ammonia emissions from soils in the upper coastal plain, North Carolina, Atmos. Environ., 36, 1087-1097, doi:10.1016/S13522310(01)00355-7, 2002.

Ruppert, J., Thomas, C., and Foken, T.: Scalar similarity for relaxed eddy accumulation methods, Bound.-Lay. Meteorol., 120, 3963, doi:10.1007/s10546-005-9043-3, 2006.

Schjoerring, J. K., Husted, S., and Mattsson, M.: Physiological parameters controlling plant-atmosphere ammonia ex- 
change, Atmos. Environ., 32, 491-498, doi:10.1016/S13522310(97)00006-X, 1998.

Simpson, D., Fagerli, H., Jonson, J. E., Tsyro, S., Wind, P., and Tuovinen J-P: Transboundary Acidification, Eutrophication and Ground Level Ozone in Europe, PART I, Unified EMEP Model Description, 104 pp., 2003.

Simpson, D., Aas, W., Bartnicki, J., Berge, H., Bleeker, A., Cuvelier, K., Dentener, F., Dore, T., Erisman, J. W., Fagerli, H., Flechard, C., Hertel, O., Jaarsveld, H. v., Jenkin, M., Schaap, M., Semeena, V. S., Thunis, P., Vautard, R., and Vieno, M.: Atmospheric transport and deposition of nitrogen in Europe, in: The European Nitrogen Assessment, edited by: Sutton, M., Howard, C. M., Erisman, J. W., Billen, G., Bleeker, A., Grennfelt, P., Grinsven, H., and Grizzetti, B., Cambridge University Press, 298-316, 2011.

Skjøth, C. A. and Geels, C.: The effect of climate and climate change on ammonia emissions in Europe, Atmos. Chem. Phys., 13, 117-128, doi:10.5194/acp-13-117-2013, 2013.

Skjøth, C. A., Hertel, O., Gyldenkaerne, S., and Ellermann, T.: Implementing a dynamical ammonia emission parameterization in the large-scale air pollution model ACDEP, J. Geophys. Res.Atmos., 109, D06306, doi:10.1029/2003JD003895, 2004.

Skjøth, C. A., Geels, C., Berge, H., Gyldenkærne, S., Fagerli, H., Ellermann, T., Frohn, L. M., Christensen, J., Hansen, K. M., Hansen, K., and Hertel, O.: Spatial and temporal variations in ammonia emissions - a freely accessible model code for Europe, Atmos. Chem. Phys., 11, 5221-5236, doi:10.5194/acp-11-52212011, 2011.

Sommer, S. G., Østergård, H. S., Løfstrøm, P., Andersen, H. V., and Jensen, L. S.: Validation of model calculation of ammonia deposition in the neighbourhood of a poultry farm using measured $\mathrm{NH}_{3}$ concentrations and $\mathrm{N}$ deposition, Atmos. Environ., 43, 915920, doi:10.1016/j.atmosenv.2008.10.045, 2009.

Sorensen, L. L., Granby, K., Nielsen, H., and Asman, W. A. H.: Diffusion Scrubber Technique Used for Measurements of Atmospheric Ammonia, Atmos. Environ., 28, 3637-3645, doi:10.1016/1352-2310(94)00189-R, 1994.

Sorensen, L., Hertel, O., Skjoth, C., Lund, M., and Pedersen, B.: Fluxes of ammonia in the coastal marine boundary layer, Atmos. Environ., 37, 167-177, doi:10.1016/S1352-2310(03)00247-4, 2003.

Stevens, C. J., Dise, N. B., Mountford, J. O., and Gowing, D. J.: Impact of nitrogen deposition on the species richness of grasslands, Science, 303, 1876-1879, doi:10.1126/science.1094678, 2004.

Sutton, M. A., Perthue, E., Fowler, D., Storetonwest, R. L., Cape, J. N., Arends, B. G., and Mols, J. J.: Vertical distribution and fluxes of ammonia at Great Dun Fell, Atmos. Environ., 31, 2615-2624, doi:10.1016/S1352-2310(96)00180-X, 1997.

Sutton, M. A., Nemitz, E., Theobald, M. R., Milford, C., Dorsey, J. R., Gallagher, M. W., Hensen, A., Jongejan, P. A. C., Erisman, J. W., Mattsson, M., Schjoerring, J. K., Cellier, P., Loubet, B., Roche, R., Neftel, A., Hermann, B., Jones, S. K., Lehman, B. E., Horvath, L., Weidinger, T., Rajkai, K., Burkhardt, J., Löpmeier, F. J., and Daemmgen, U.: Dynamics of ammonia exchange with cut grassland: strategy and implementation of the GRAMINAE Integrated Experiment, Biogeosciences, 6, 309331, doi:10.5194/bg-6-309-2009, 2009.
Sutton, M. A., Oenema, O., Erisman, J. W., Leip, A., van Grinsven, H., and Winiwarter, W.: Too much of a good thing, Nature, 472, 159-161, doi:10.1038/472159a, 2011.

Velthof, G. L., van Bruggen, C., Groenestein, C. M., de Haan, B. J., Hoogeveen, M. W., and Huijsmans, J. F. M.: A model for inventory of ammonia emissions from agriculture in the Netherlands, Atmos. Environ., 46, 248-255, doi:10.1016/j.atmosenv.2011.09.075, 2012.

Walker, J. T., Jones, M. R., Bash, J. O., Myles, L., Meyers, T., Schwede, D., Herrick, J., Nemitz, E., and Robarge, W.: Processes of ammonia air-surface exchange in a fertilized Zea mays canopy, Biogeosciences, 10, 981-998, doi:10.5194/bg-10-9812013, 2013.

Wang, L., Xu, Y., and Schjoerring, J. K.: Seasonal variation in ammonia compensation point and nitrogen pools in beech leaves (Fagus sylvatica), Plant Soil, 343, 51-66, doi:10.1007/s11104010-0693-7, 2011.

Wang, L., Ibrom, A., Korhonen, J. F. J., Arnoud Frumau, K. F., Wu, J., Pihlatie, M., and Schjoerring, J. K.: Interactions between leaf nitrogen status and longevity in relation to $\mathrm{N}$ cycling in three contrasting European forest canopies, Biogeosciences, 10, 9991011, doi:10.5194/bg-10-999-2013, 2013.

Wichink Kruit, R. J., van Pul, W. A. J., Otjes, R. P., Hofschreuder, P., Jacobs, A. F. G., and Holtslag, A. A. M.: Ammonia fluxes and derived canopy compensation points over non-fertilized agricultural grassland in The Netherlands using the new gradient ammonia - high accuracy - monitor (GRAHAM), Atmos. Environ., 41, 1275-1287, 2007.

Wichink Kruit, R. J., Schaap, M., Sauter, F. J., van Zanten, M. C., and van Pul, W. A. J.: Modeling the distribution of ammonia across Europe including bi-directional surface-atmosphere exchange, Biogeosciences, 9, 5261-5277, doi:10.5194/bg-9-52612012, 2012.

Wyers, G. P. and Erisman, J. W.: Ammonia exchange over coniferous forest, Atmos. Environ., 32, 441-451, doi:10.1016/S13522310(97)00275-6, 1998.

Wyers, G. P., Vermeulen, A. T., and Slanina, J.: Measurement of Dry Deposition of Ammonia on a Forest, Environ. Pollut., 75, 25-28, doi:10.1016/0269-7491(92)90052-C, 1992.

Xiankai, L., Jiangming, M., and Shaofeng, D.: Effects of nitrogen deposition on forest biodiversity, Acta Ecologica Sinica, 28, 5532-5548, doi:10.1016/S1872-2032(09)60012-3, 2008.

Zhang, L., Wright, L. P., and Asman, W. A. H.: Bi-directional airsurface exchange of atmospheric ammonia: A review of measurements and a development of a big-leaf model for applications in regional-scale air-quality models, J. Geophys. Res.-Atmos., 115, D20310, doi:10.1029/2009JD013589, 2010. 